\title{
KULOUK KERINCI DALAM KARYA MAHKOTA PUTAI
}

\author{
Reno Nopia ${ }^{1^{*}}$, Ahmad Akmal ${ }^{2 *}$, Yuniarti Munaf ${ }^{3 *}$ \\ Minat Penciptaan Seni Kriya Program Pascasarjana \\ Institut Seni Indonesia Padang Panjang \\ Jl. Bahder Johan, Guguak Malintang, Padangpanjang, Kota Padangpanjang, 27126. \\ Sumatera Barat. Indonesia. \\ Email: rennanopia@gmail.com
}

\begin{abstract}
Abstrak
Kulouk merupakan salah satu pelengkap pakaian berupa penutup kepala yang dipakai sebagai mahkota pengantin perempuan masyarakat Melayu Kerinci. Penciptaan karya dengan judul "Kulouk Kerinci dalam Karya Mahkota Putai" bertujuan untuk menghadirkan kembali makna filosofis tentang perempuan Kerinci yang terdapat pada kulouk Kerinci yaitu pada bagian lingkaran gelang dan tujuh kunci pada kulouk Kerinci menjadikan karakter perbedaan perempuan Kerinci dengan perempuan daerah lainnya. Hiasan pelengkap kulouk mengandung makna filosofis tentang peran perempuan Kerinci Lingkaran gelang dan tujuh kunci di sebelah kanan gelang kulouk mencerminkan sifat-sifat perempuan yang harus dijunjung tinggi oleh para perempuan dalam kehidupan masyarakat Kerinci. Kulouk Kerinci sebagai ide penciptaan karya seni dalam perancangan kreasi dalam bentuk mahkota putai sebagai salah satu karakter yang mewakili bentuk kulouk Kerinci. Metode yang dipakai untuk penciptaan karya yaitu melalui observasi, wawancara, dokumentasi dan proses kreasi arstistik diantaranya eksperimen,perenungan serta pembentukan desain. Karya ini melahirkan penciptaan karya mahkota putai yang dirancang menjadi tiga bentuk desain yaitu difungsikan untuk perempuan remaja, perempuan dewasa dan perempuan tua. Penciptaan karya memaknai perempuan yang diistimewakan, perempuan yang dijunjung tinggi mempunyai sifat dan peran perempuan yang terdapat pada kulouk Kerinci.
\end{abstract}

Kata Kunci: Kulouk, Hiasan Kepala Perempuan, Kerinci.

\begin{abstract}
Kulouk is one of the complementary clothing in the form of a head covering that is used as the crown of the Melayu Kerinci community bride. The creation of the work entitled "Kulouk Kerinci in Mahkota Putai's Work" aims to bring back the philosophical meaning of Kerinci women contained in Kerinci's kulouk in the circle section of the bracelet and the seven keys in the Kerinci kulouk make the character of Kerinci's women's differences with other regional women. Kulouk complementary decoration contains philosophical meaning about the role of Kerinci women. The circle of the bracelet and the seven keys to the right of the kulouk bracelet reflect the qualities of women that women must uphold in the life of the Kerinci community. Kulouk Kerinci as an idea of the creation of works of art in the design of creations in the form of a putai crown as one of the characters representing the form of Kerinci's kulouk. The method used for the creation of works is through observation, interviews, documentation and the process of artistic creation including experimentation, reflection and design formation This work gave birth to the creation of the Putai crown work which was designed into three forms of design, namely for young women, adult women and old women. Creation of works means women who are privileged, women who are upheld have the nature and role of women found in the Kerinci curriculum.
\end{abstract}

Keywords: Kulouk, Headdress for Women, Kerinci

\section{PENDAHULUAN}

Kulouk merupakan salah satu pelengkap pakaian berupa penutup kepala yang dipakai oleh perempuan Kerinci. Cara pemakaiannya kulouk dipasangkan di atas kepala. Kulouk yang dijadikan objek penciptaan merupakan kulouk yang ada di daerah Kerinci Tengah, karena kulouk daerah Kerinci ini berbeda dengan daerah lainnya. Kulouk yang ada pada objek penciptaan kegunaannya untuk upacara adat perkawinan dan adat dalam kenduri sko (pusaka atau pusako) yang dipakai oleh anak betino (perempuan) dalam luhak Kerinci Tengah. Pemakaian kulouk dilengkapi dengan busana pendukung yaitu baju kurung, kain panjang dan selendang (Yusna, Wawancara, 07 Februari 2018).

Kulouk tidak hanya sebagai penutup kepala, tetapi juga sebagai mahkota pengantin wanita masyarakat Melayu Kerinci. Bentuk kulouk secara umum terdiri dari lingkaran besar (2 gelang besar), lidah atau 


\section{Gorga Jurnal Seni Rupa \\ Volume 07 Nomor 02 \\ p-ISSN: 2301-5942 | e-ISSN: 2580-2380}

jumbei (selembar kain beludru dengan ukuran 8-10 $\mathrm{cm}$ ) yang dipasang pada bagian atas lingkaran (gelang) sampai belakang kepala sebatas pinggang. Berbagai unsur motif hiasan sebagai pelengkap bentuk kulouk adalah cincin, batu cincin, kuningan, umbei (hiasan berbentuk segitiga), kuncai (kunci), kain blie (kain belang) 4 warna yaitu hitam, kuning, putih dan merah, manik-manik motif bunga dan payet piring serta renda berwarna kuning emas.

Bentuk lingkaran atau gelang pada kulouk mempunyai makna yang menggambarkan peranan perempuan dengan tanggung jawabnya. Peranan perempuan yang dimaksud merupakan perempuan yang sudah menikah, ia harus tunduk dan patuh serta dibimbing oleh suaminya. Sebagai perempuan ia adalah isteri dan ibu dari anak-anaknya, ia harus mampu mendidik anak-anaknya dan mengurusi rumah tangganya (Meka Algazi, Wawancara, 07 Februari 2018).

Pemaknaan dalam bentuk lingkaran kulouk dan kelengkapan penghiasnya mencerminkan sifat-sifat perempuan yang harus dijunjung tinggi oleh para perempuan dalam kehidupan masyarakat Kerinci. Lebih lanjut dijelaskan oleh Meka Algazi bahwa:

"Keberadaan kulouk dengan kelengkapan penghiasnya pada masa lalu (1940-an) mengandung makna filosofis bagi pemakainya. Bentuk lingkaran seperti gelang pada tingkatan satu kulouk menyimbolkan bahwa perempuan setelah menikah tunduk, patuh, taat dan dilindungi oleh suaminya. Fungsi kunci di sebelah kanan gelang kulouk mempunyai makna peran perempuan dalam berumah tangga. Artinya perempuan mempunyai peran penting dalam rumah tangga dan ia mempunyai tanggung jawab besar yang harus di jalankan" (Wawancara, 09 Februari 2018).

Pendapat di atas memberikan informasi bahwa banyak makna filosofis yang terdapat pada kulouk sebagai penutup kepala, tetapi makna filosofis pada kulouk tersebut sudah tidak diketahui lagi oleh perempuan Kerinci masa sekarang. Hal ini disebabkan kurangnya edukasi ilmu pengetahuan dan sedikitnya masyarakat Kerinci yang meneliti, menggali dan mengenali kembali tentang benda budaya tradisi salah satunya kulouk sehingga makna filosofis pada kulouk hanya tersimpan di memori nenek moyang terdahulu yang mengakibatkan nilai-nilai simbol tradisi pada kulouk tidak diketahui dan dipahami pada masa sekarang. Fungsi kulouk bukan sebagai penutup kepala saja, namun pada perlengkapan atau penghias kulouk ada makna yang perlu diketahui dan dipahami dalam kehidupan masyarakat Kerinci, terutama kaum perempuan. Adapun makna yang terdapat pada kulouk menurut Iskandar Zakaria di jelaskan bahwa;

"Makna dan hiasan pelengkap kulouk pada masa lalu (1940-an) mempunyai makna filosofis terkait dengan peranan perempuan dalam kehidupan masyarakat Kerinci dengan simbol tujuh kunci hiasan pelengkap di sebelah kanan lingkaran gelang pada kulouk. Keberadaan kunci di sebelah kanan memaknai sebuah kebaikan, karena kaum perempuan merupakan lambang kebaikan atau kunci kebaikan. Tujuh kunci tersebut juga untuk memaknai peranan perempuan dalam berumah tangga yaitu sebagai pemegang kunci yang tujuh yaitu kunci umouh, kunci kamar, kunci bilik (lumbung padi), kunci pura, kunci peti, kunci dapur dan kunci hati” (Wawancara, 19 April 2018).

Mencermati uraian di atas, pengkarya sebagai perempuan daerah Kerinci tertarik untuk mengangkat tema tentang "Makna Filosofis kulouk Kerinci dalam Karya Mahkota Putai" karena pada kulouk ada nilainilai budaya, simbol adat yang tidak diketahui dan tidak dipahami oleh masyarakat Kerinci masa sekarang. Berdasarkan fenomena yang terjadi pada masyarakat Kerinci pengkarya mencoba menghadirkan kembali makna filosofis yang terdapat pada kulouk Kerinci dalam karya berbentuk mahkota dengan mengambil salah satu bentuk yang mewakili karakter kulouk Kerinci yaitu adanya lingkaran gelang, kuncai (kunci) dan motif yang melengkapi bentuk kulouk Kerinci. Penciptaan karya mahkota terinspiransi dari makna filosofis kulouk Kerinci ini diciptakan bahwasannya ada nilai-nilai sosial yang dapat di pelajari dari kulouk sebab dengan memahami atau paham makna yang terkandung pada kulouk tentu perempuan berusaha menjaga harkat martabat sebagai isteri dan ibu dari anak-anaknya.

Adanya makna filosofis yang terdapat pada kulouk menjadikan salah satu bentuk karakter kulouk Kerinci sangat penting untuk mewakili bentuk karya mahkota putai yang diciptakan melalui pengembangan kreasi bentuk mahkota dengan mengambil karakter yang terdapat pada kulouk Kerinci yaitu kelengkapan penghias kulouk dengan memanfaatkan motif matoahai (matahari) serta memakai teknik sulam tangan.

Kreasi merupakan pembaharuan dengan bentuk ulang dari apa yang telah terwujud, namun bentuk pengulangan variasinya masih dalam pola yang telah ada tetapi menghasilkan bentuk yang baru (Djelantik, 2004: 67). Pendapat tersebut dapat digunakan untuk pengembangan bentuk kreasi yang akan diciptakan pada bentuk garapan karya seni mahkota putai dilihat 


\section{Gorga Jurnal Seni Rupa \\ Volume 07 Nomor 02 \\ p-ISSN: 2301-5942 | e-ISSN: 2580-2380}

dari jumlah gelang (lingkaran kulouk), teknik, warna dan hiasan pendukung. Jumlah gelang pada karya seni mahkota putai untuk menentukan siapa yang memakainya, karena masyarakat Kerinci menjadikan jumlah gelang atau tingkatan gelang sebagai simbol pemakainya. Meka Algazi mengatakan bahwa setiap benda yang menghiasi benda tradisi seperti kulouk, busana dan motif yang digunakan semuanya mempunyai simbol. Simbol diterapkan untuk pengganti bahasa ucapan karena masyarakat Kerinci mempunyai sifat-sifat menjaga etika, adat dalam bahasa dan tingkahlaku (Wawancara, 19 April 2018).

Penggarapan karya untuk mahkota tingkat satu (gelang) difungsikan untuk remaja perempuan. Gelang tingkat dua untuk perempuan dewasa. Tingkat lima difungsikan untuk perempuan tua.Penciptaan kreasi bentuk mahkota putai difokuskan untuk keperluan upacara adat perkawinan yang dipakai oleh remaja perempuan, perempuan dewasa dan perempuan tua yang melaksanakan upacara adat perkawinan tersebut. Pemakaian mahkota putai didukung dengan memakai baju kurung, thap dan salempang. Baju kurung, thap dan salempang hanya sebagai pendukung karya kulouk pada saat karya difashion show kan. Pemakaian baju kurung pada saat fashion show akan lebih memudahkan masyarakat untuk mengetahui siapa yang memakai mahkota. Pemakaian baju kurung bagi masyarakat Kerinci terdapat perbedaan untuk menentukan siapa yang memakainya, perbedaan tersebut dilihat pada kedalaman baju kurung yang dipakai (Alimin, Wawancara, 20 April 2018).

Hiasan pendukung penciptaan karya seni mahkota putai memanfaatkan motif matoahai karena motif matoahai merupakan salah satu motif tradisi masyarakat Kerinci yang digunakan untuk menghiasi dinding Masjid dan dinding Rumah Tradisional Kerinci (umah lahiek). Bentuk motif matoahai dibentuk dengan gabungan berbagai motif yang membentuk satu kesatuan seperti gabungan lingkaran kemudian diisi dengan motif kembang bunga yang dibentuk menyerupai matahari yang sedang bersinar (Alipuddin, 2017 : 122). Matoahai dalam bahasa Kerinci berarti dalam dalam bahasa Indonesia adalah matahari. Buku yang berjudul "Republik Ken Arok" menjelaskan:

Matahari merupakan sebuah simbol tertinggi di langit dari kehadiran Allah SWT karena matahari selalu memberikan sinarnya dan bermanfaat bagi seluruh makhluk di muka bumi dan ibu (perempuan) menjadi simbol tertinggi di bumi dari kehadiran-Nya. Salah satu simbol kehadiran muncul dari Sabda Nabi
Muhammad SAW, menjelaskan "ibumu, ibumu, ibuти sebagai sosok yang paling dihormati di rumah, baru kemudian ayahmu (Candra Malik, 2016: 15).

Mencermati uraian di atas, bahwa motif motoahai merupakan salah satu motif yang cocok menjadi pilihan untuk menghiasi mahkota putai sebagai simbol perempuan karena perempuan selain berperan sebagai isteri ia juga seorang ibu. Menyingkronkan nilai makna yang terdapat pada mahkota putai dengan matoahai yaitu kemampuan memberikan energi positif kesemua orang, terutama diri sendiri, keluarga dan masyarakat. Motif matoahai pada karya sebagai simbol ibu (perempuan) dan isteri digunakan sebagai hiasan pelengkap untuk menghiasi mahkota yang dikreasikan dalam bentuk motif ukuran besar dan kecil.

Penciptaan karya mahkota putai menggunakan kreasi motif matoahai untuk menghiasi di sekeliling lingkaran mahkota. Motif ini disulam menggunakan sulam benang emas dan sulam payet dengan penambahan permata, payet dan diwujudkan dalam bentuk 2 dimensi secara dekoratif. Pemilihan warna untuk mahkota yang akan digarap menggunakan warna hijau, kuning, biru, hitam, merah dan putih. Warna-warna ini sebagai warna khas daerah Kerinci. Melalui penciptaan karya sengaja menggunakan warna-warna khas daerah Kerinci karena pengkarya mengharapkan pada penciptaan karya kreasi bentuk mahkota putai memiliki karakter warna-warna khas masyarakat Kerinci.

\section{KAJIAN TEORI}

\section{Teori Desain}

John A Walker dalam bukunya "Desain Sejarah Budaya Sebuah Pengantar Komprehensif" menjabarkan banyak cara untuk menciptakan desain seperti dijelaskan bahwa; desain mempunyai dua tujuan yang berbeda-beda seperti memahami (understanding enconding) dan menciptakan (creating, encoding), yang meliputi aspek kebendaan, kemanusian, fisik, non fisik, konkret, abstrak, tubuh, pikiran, material dan non material. Pengetahuan desain sangat luas cakupannya yang melibatkan data indrawi, kesadaran, ketaksadaran, perasaan, emosi, ide-ide, konsep, intuisi, bahkan yang tak terkatakan atau tak-terjelaskan (tacit knowledge). Desain terdiri dari empat kategori objek yang saling berkaitan satu sama lainnya seperti ; a) artefak (benda, produk, sarana, prasarana, fasilitas, alat dan mesin), b) manusia (pikiran, perasaan, mental, kesadaran, ketaksadaran, pengalaman dan emosi), c) konsep 


\section{Gorga Jurnal Seni Rupa \\ Volume 07 Nomor 02 \\ p-ISSN: 2301-5942 | e-ISSN: 2580-2380}

(simbol, tanda, nilai dan makna), d) lingkungan (Walker, 1989:7-10).

Mencermati teori desain di atas, dipakai untuk pengembangan desain bentuk-bentuk kreasi penggarapan mahkota dengan memperhatikan bentukbentuk desain rancangan sesuai dengan kebutuhan atau karakter perempuan yang memakainya. Perempuan remaja bentuk desain mahkota dirancang lebih sederhana hal ini untuk menyesuaikan karakter perempuan yang beranjak remaja lebih aktif dalam berbagai aktivitas dan masih belum memperhatikan cara berpenampilan. Jadi bentuk desainnya dirancang lebih sederhana dan mempunyai daya tarik tersendiri. Mahkota untuk perempuan remaja dirancang dengan bentuk desain satu tingkatan lingkaran gelang. Bentuk desain motif di sekeliling lingkaran, terlihat simpel dan sederhana. Desain untuk perempuan dewasa dirancang dengan rancangan desain yang lebih elegan dan modis karena perempuan dewasa selalu ingin bergaya dan mempunyai keinginan menampilkan kecantikannya gaya yang elegan.

Bentuk desain dirancang dua tingkatan lingkaran dengan motif yang full menampakkan warna-warna yang cerah dan modis dalam stelannya. Desain untuk perempuan tua, bentuk desain dirancang lebih elegan dari perempuan dewasa, hal ini terkait bahwa perempuan tua ikut menyenangi stelan anak muda yang ingin tetap terlihat muda dan modis. Bentuk rancangan desain perempuan tua dirancang dengan bentuk desain lima tingkatan lingkaran gelang dengan bentuk motif pendukung hanya di bagian-bagian tertentu saja yang menjadi titik pusat.

\section{Teori Warna}

Warna adalah unsur desain yang paling menonjol, dengan adanya warna menjadikan suatu benda dapat dilihat, warna dapat mengungkapkan suasana perasaan atau watak benda yang akan di rancang. Warna dapat menunjukkan sifat dan watak yang berbeda-beda, bahkan mempunyai variasi yang sangat banyak (Ernawati, 2002: 76). Warna didefinisikan sebagai getaran atau gelombang yang diterima indera penglihatan indera manusia berasal dari pancaran cahaya melalui sebuah benda (Susanto, 2012:433).

Berdasarkan uraian tentang warna di atas, bahwa warna-warna sangat diperlukan dalam karya seni agar bentuk karya mempunyai variasi yang berbeda-beda. Penggarapan karya seni mahkota menggunakan warna hijau, kuning, biru, hitam, merah dan putih yang merupakan warna khas daerah Kerinci kemudian warna-warna dikombinasikan dengan warna yang kontras.

\section{Teori Fungsi}

Menurut Dharsono Soni Kartika keberadaan karya seni secara teoritis terbagi atas tiga fungsi yaitu fungsi personal, fungsi sosial dan fungsi fisik. Adapun fungsi-fungsi tersebut dijelaskan sebagai berikut;

Fungsi personal sebagai instrumen ekspresi personal, seni semata-mata tidak dibatasi untuk dirinya sendiri. Maksudnya ia tidak secara eksklusif dikerjakan berdasarkan emosi pribadi, namun bertolak pada pandangan personal menuju persoalan-persoalan umum dimana seniman itu hidup yang nantinya akan diterjemahkan seniman lewat lambang simbol. Fungsi sosial merupakan kencenderungan atau usaha untuk mempengaruhi tingkah laku terhadap kelompok manusia. Ia diciptakan berdasarkan atas dasar penggunaannya pada situasi umum serta menggambarkan aspek kelompok sebagai wujud adanya perbedaan pengalaman personal. Fungsi fisik yang dimaksud berupa kreasi yang secara fisik dapat digunakan untuk kebutuhan praktis sehari-hari. Karya seni yang dibuat benar-benar merupakan kesenian yang berorientasi pada kebutuhan fisik selain keindahan barang itu sendiri (2017: 30-31).

Berdasarkan teori fungsi di atas, bahwa karya seni diciptakan mempunyai tiga fungsi ; a) Fungsi personal merupakan sebuah ungkapan pribadi pengkarya tentang mahkota yang akan diciptakan sesuai dengan pandangan pribadi tentang hal yang berkaitan dengan kulouk. b)Fungsi sosial sebagai alat komunikasi untuk menyampaikan pesan makna simbolis yang terdapat pada karya seni kulouk. c) Fungsi fisik dari karya seni kulouk sebagai mahkota yang diletakkan di atas kepala setelah menggunakan jilbab sebagai simbol dari perempuan.

\section{METODE PENCIPTAAN \\ 1.Riset Emik \\ 1).Observasi}

Observasi dilakukan dengan mengamati bentuk kulouk kulouk yaitu bentuk lingkaran kulouk, kunci dan motif yang terdapat pada kulouk Kerinci atau susunan bentuk hiasan pelengkap yang ada pada kulouk, warna, bahan, teknik dan makna-makna filosofis yang ada pada kulouk. Setelah melakukan pengamatan pada bentuk kulouk Kerinci pengkarya melakukan langkahlangkah metode dalam penciptaan karya 1) Mengambil karakter lingkaran kulouk untuk penciptaan karya mahkota dengan melakukan pengembangan tingkatan lingkaran gelang pada karya dan menyesuaikan makna filosofis yang terkandung 


\section{Gorga Jurnal Seni Rupa \\ Volume 07 Nomor 02 \\ p-ISSN: 2301-5942 | e-ISSN: 2580-2380}

pada kulouk Kerinci. Kemudian dirancangkan dengan pengembangan tiga karakter desain yaitu satu tingkatan, dua tingkatan dan lima tingkatan 2). Melakukan pengembangan pada bentuk hiasan kunci yang terdapat pada kulouk Kerinci dengan perancangan bentuk kunci pada karya diganti dengan rantai berwarna kuning emas yang terdiri dari masingmasing rantai berjumlah tujuh rantai, tiga rantai dan satu rantai di bagian kanan-kiri lingkaran gelang pada penciptaan karya. 3) Melakukan pengembangan bentuk motif yang terdapat pada kulouk Kerinci. Pengkarya menggunakan motif matoahai sebagai motif untuk menghiasi lingkaran gelang pada penciptaan karya mahkota karena berdasarkan pengamatan motif matoahai merupakan salah satu motif yang cocok untuk menghiasi penciptaan karya sebagai simbol dari perempuan. 4) Melakukan pengembangan terhadap teknik, bahan dan warna yang digunakan dalam penciptaan karya. Pengkarya menggunakan teknik jahit pemasangan payet untuk membentuk motif matoahai pada karya. Menghadirkan karakter warna-warna kontras yang mencirikan warna khas masyarakat Kerinci.

\section{2).Wawancara}

Wawancara merupakan kegiatan mencari informasi, keterangan, pendapat dengan cara mencatat dan merekam apa yang didengar dari narasumber terkait dengan kulouk Kerinci. Melalui proses tanyajawab dengan narasumber yang memberi informasi untuk mengungkapkan latarbelakang sejarah kulouk Kerinci pada zaman lampau hingga zaman sekarang. pengkarya melakukan wawancara dengan beberapa budayawan di daerah Kerinci di antaranya dengan Meka Algazi , Iskandar Zakaria dan Alimin.

\section{3).Dokumentasi}

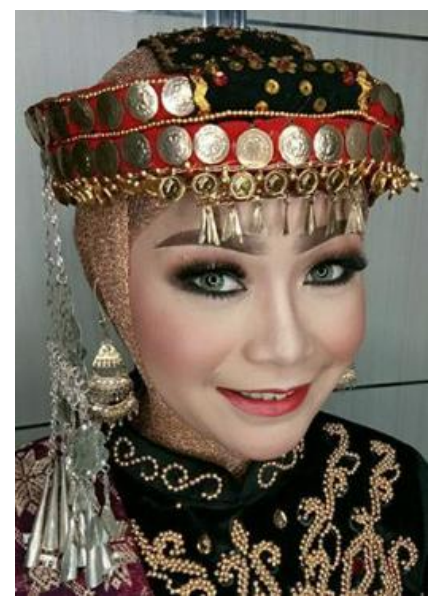

Gambar 1.

Perempuan Kerinci dengan memakai kulouk Kerinci Foto Koleksi: Rio Makeup, 2018 Foto Repro : Rena Nopia
Gambar 1 di atas merupakan gambar acuan untuk penciptaan karya mahkota putai. Pada gambar terlihat perempuan Kerinci menggunakan kulouk Kerinci dengan lingkaran gelang kulouk berwarna merah dan hiasan motif atau cincin yang menghiasi lingkaran gelang berwarna kuning emas. Bagian sisi kanan terlihat bentuk kunci terbuat dari logam berwarna putih dengan panjang sampai di bawah bahu serta bagian atas lingkaran terdapat lidah kulouk berwarna hitam. Penciptaan karya lebih memfokuskan acuan kepada makna yang terdapat pada lingkaran kulouk dan makna kunci yang terdapat pada kulouk dengan mengambil krakter kulouk untuk penciptaan karya mahkota putai salah satunya yaitu lingkaran kulouk, kunci dan susunan bentuk cincin pada kulouk sebagai sumber ispirasi untuk penciptaan bentuk mahkota putai.

\section{Proses Kreasi Artistik}

Proses kreasi artistik merupakan pemanfaatan data yang diperoleh dari data emik maupun etik yang digunakan dalam eksplorasi karya yang terdiri dari eksperimen, perenungan dan pembentukan

\section{HASIL DAN PEMBAHASAN \\ 1. Hasil Karya}

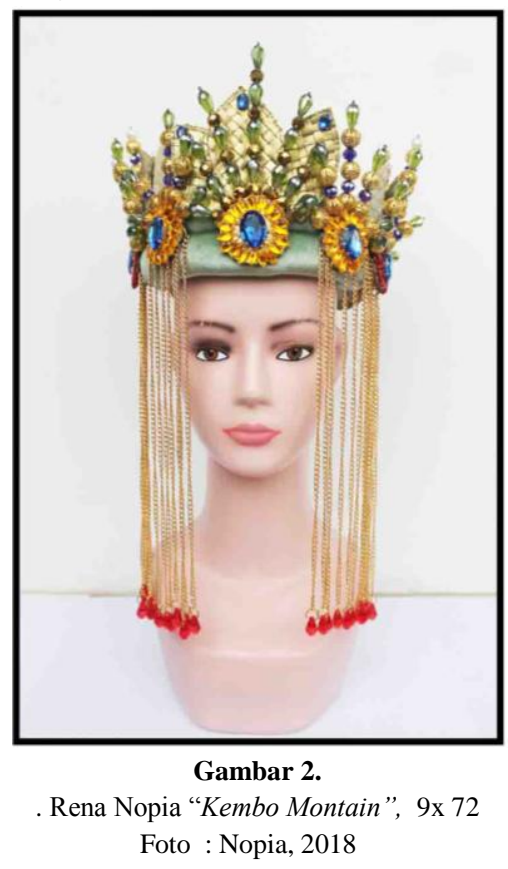

\section{1).Deskripsi Karya}

Karya dengan judul "Kembo Muntain" dibuat pada tahun 2018, dirancang dua tingkatan lingkaran berwarna hijau muda. Bahan yang digunakan kain beludru Arab warna hijau muda, mutiara cacko warna merah, biru muda, kuning emas dan rantai berwarna kuning serta dacron sebagai isian lingkaran mahkota, 


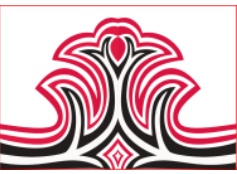

payet, swaroski, kawat dan anyaman dari bahan tikar pandan.

Bentuk karya didukung dengan tujuh susunan motif matoahai yang menghiasi di sekeliling lingkaran gelang mahkota dan terdapat tiga motif utama yaitu pada bagian depan, samping kanan dan kiri. Tiga motif tersebut diberi landasan anyaman dari bahan tikar pandan berwarna kuning emas. Motif pada karya terlihat dua karakter yang dimunculkan yaitu bentuk susunan payet berwarna kuning dan merah mengikuti pola bulat pada motif. Kemudian menghadirkan bentuk garis vertikal, diagonal dan horizontal dengan kombinasi warna hijau muda, kuning emas serta warna biru. Beberapa bentuk motif diberi untaian rantai berwarna kuning emas sampai batas bahu, masing masing rantai berjumlah tujuh untaian rantai.

\section{2).Interpretasi}

Karya dengan judul "Kembo Montain" diartikan dalam bahasa Indonesia pengantin perempuan. Bentuk karya ini mengungkapkan makna nilai filosofis tanggung jawab perempuan ketika sudah menikah ia diharuskan taat kepada suami, menjaga kehormatan diri sendiri, mendidik anak-anaknya, memelihara kerukunan rumah tangga, menjalankan ajaran agama, menjaga ucapan atau tingkah laku yang baik kepada suami dan belajar membuat kebaikan dalam segala hal.

\section{3).Pembahasan Karya}

Kulouk Kerinci merupakan pelengkap pakaian berupa mahkota yang digunakan untuk menutupi kepala perempuan Kerinci. Setiap hiasan pelengkap pada kulouk Kerinci mengandung nilai filosofis yang menggambarkan sifat-sifat perempuan masyrakat Kerinci seperti kelengkapan tujuh kunci yang terdapat pada lingkaran kulouk dibagian kanan kulouk sebagai simbol lambang kebaikan. Artinya kaum perempuan merupakan lambang kebaikan atau kunci kebaikan yang berarti jika tabiat perempuan tidak baik dalam masyarakat maka akan rusaknya masyarakat tersebut. Kunci tersebut adalah kunci: 1) umah (rumah). 2) kunci kamar, 3) kunci bilik (lumbung padi), , 4) pura (tempat menyimpan uang), 5) kunci peti, peti 6) kunci dapur, 7) dan kunci hati.

Makna nilai filosif yang terdapat pada kulouk diatas menjadikan inspiransi pengkarya menciptakan karya mahkota Putai dengan membuat tiga desain mahkota yang difungsikan untuk perempuan remaja, dewasa dan perempuan tua. Setiap bentuk karya yang dihadirkan bertujuan untuk menghadirkan makna dan nilai yang mencerminkan sifat dan peran perempuan ang mengajukan pada kulouk Kerinci.
Gorga Jurnal Seni Rupa

Volume 07 Nomor 02

p-ISSN: 2301-5942 | e-ISSN: 2580-2380

\section{KESIMPULAN DAN SARAN}

\section{Kesimpulan}

Penciptaan karya mahkota putai Kerinci ini terinspiransi dari makna-makna dan nilai filosofis yang terkandung pada bentuk lingkaran gelang dan tujuh kunci yang terdapat pada kulouk. Pada bentuk lingkaran dan tujuh kunci yang terdapat pada kulouk mencerminkan sifat perempuan yang harus dijunjung tinggi yang harus tetap dilestari budayakan hingga sampai saat ini. Makna lingkran tersebut memaknai bahwa ketika perempuan sudah menikah ia harus patuh dengan suaminya sesuai dengan aturan adat dan agama karena ketika sudah memiliki suatu ikatan.

Sedangkan makna tujuh kunci yang terdapat pada kulouk memaknai peran perempuan dalam kehidupan berumah tangga yaitu perempuanlah yang memegang tujuh kunci tersebut bermula dari kunci rumah, kunci kamar, kunci peti, kunci dapur, kunci bilik, kunci pura dan kunci hati perempuanlah yang mengatur semua hal tersebut. Perwujudan bentuk karya kulouk ini didukung dengan motif matoahai sebagai hiasan pelengkapa dan sebagai simbol perempuan yang memakai kulouk dan menggunakan kombinasi warna tradisi masyarakat Kerinci yaitu warna merah, kuning, hijau, putih, biru dan hitam. Bentuk perwujudan karya ini bertujuan untuk menghadirkan kembali maknamakna nilai filosofis tentang perempuan yang terdapat pada kulouk Kerinci.

\section{Saran}

Pengkarya mengharapkan para penikmat seni, mahasiswa ISI Padangpanjang agar dapat menerima karya seni mahkota Kerinci dengan menggunakan teknik pasang payet. Diharapkan juga karya yang diciptakan dapat dijadikan sumber acuan berkarya bagi pencinta dunia seni kriya.

\section{DAFTAR RUJUKAN}

Djelantik, A. A. M. 2004. Estetika Sebuah Pengantar. Bandung: Masyarakat Seni Pertunjukan Indonesia.

Ernawati, 2002. Pengetahuan Tata Busana. Padang: Universitas Negeri Padang Press.

Kartika, Dharsono Soni. 2017. Seni Rupa Modren. Edisi Revisi. Bandung: Rekayasa Sains. Bandung.

Malik, Candra. 2016. Republik Ken Arok. Jakarta : Kepustakaan Populer Gramedia.

Walker. John A. 1989. Desain Sejarah Budaya Sebuah Pengantar Komprehensif. Jakarta: Jalasutra.2 